\title{
Household Waste Management For The Achievement Of SDGs In Bulak Surabaya
}

\author{
Sindy Rukmana Pratiwi', ${ }^{2}$ F. Rooslan Edy Santosa \\ Narotama University \\ rukmana.sindy@gmail.com
}

\begin{abstract}
The purpose of this study was to determine the conduct or description about household waste management in the district of Bulak Surabaya by using studies EHRA (Environmental Health Risk Assessment) where a study of participation in the District / City to understand the conditions of sanitation facilities and hygiene as well as societal attitudes on a scale house stairs. This research was conducted by field observations and interview. District activities and respondents are randomly assigned study area. Based upon the results of research studies EHRA in District of Bulak Surabaya, there are 200 respondents, only a small proportion of respondents who perform household waste management around $19.5 \%$, while those who are not managing $80.5 \%$ achievement SDGs taken from point 6 "Water and sanitation" where trash organic collected in TPS (temporary disposal sites) can be treated with an organic fertilizer made so that the waste that goes to landfill (landfill) was reduced by 40 tons a day.
\end{abstract}

Keywords: waste management, EHRA, SDGs

\begin{tabular}{|c|c|c|}
\hline Received & Revised & Published \\
\hline 11 January 2019 & 17 February 2019 & 30 March 2019 \\
\hline
\end{tabular}

\section{INTRODUCTION}

SDGs (Sustainable Development Goals) is a new development that encourages change towards sustainable development by mutual agreement. Of the 193 countries that participated in the UN, Indonesia demonstrated high commitment to succeed in achieving the SDGs destination 17 on July 4, 2017, the signing of the Presidential Decree 59 the Year 2017 on the Implementation of Sustainable Development Goals.

In Indonesia, the population growth is very significant in every year cause the waste generated from the activity and consumer spending also increased. According Kardono (2007) 
reported annually Indonesia had increased the volume of waste as much as $2-4 \%$. Garbage derived from activities of household activities, industry and trade.

Trash with large numbers also pose a threat of environmental pollution, such as flooding until the outbreak of the disease. According to the Ministry of Environment (2008), in Indonesia the majority of incoming waste classified as organic waste from the whole is $58 \%$ while $14 \%$ of plastic waste and paper waste as much as $9 \%$. In the area of Surabaya, the population growth increases significant, as a result of population increase in every year that often leads to waste resulting from the activity and consumer spending also increased. Approximately 1,200 tonnes/day of waste collected in this city. According to journalist Ahmad Faizal at Reuters TV A lot of unsorted household waste disposal. "Mayor of Surabaya, Tri Rismaharini, claims due to 'treatment' special against garbage, a supply of garbage from the traditional market in Surabaya that goes to landfill was reduced by 40 tons a day". Kenjeran region Surabaya, contained Super depot Sutorejo, in this area garbage is separated according to its kind that is organic and nonorganic. Most of the organic waste is channeled in home composting in Surabaya, whereas for the non-organic garbage partially recycled. From his daily 1.200 ton about $20 \%$ of incoming waste in composting with obtained into compost for the plants in the garden city, for the remainder of the management of waste in the landfill at (landfill),

Environmental health risk assessment study (EHRA) is a study to understand the conditions of sanitation and hygiene facilities as well as the behavior of people in the household. EHRA study focuses on sanitation facilities and people's behavior, such as drinking water, garbage disposal services, latrines, and sewerage households.

\section{METHODS}

The location of research conducted in the District of Bulak, District Bulak including Surabaya area north location of the research will focus on thesub-district sanitation. (According to the District of Bulak in number, 2017) District of Bulak has an area of $6.72 \mathrm{~km}^{2} \pm$ there are four villages, the village Bulak, Village Kedung Cowek, New Sukolilo Village, and Village Kenjeran there are 21 neighborhoods and 131 RT's.

Collecting data in this study is looking for information that is primary or secondary. Primary data were obtained from field observation activities, distribution of questionnaires, drawing documentation, and interviews. The interview in question is by asking questions directly to the Community District of Bulak by way of question and answer, and the data retrieved from the rules laid out in the questionnaire EHRA. 
secondary data in this study come from the archives that can be obtained from Surabaya BPS data, or books from previous research that can support researchers in analyzing the problems studied.

This research is qualitative and quantitative, qualitative research which aims to understand the study area, such as behavior, action, or describe and explain the quality of social influences that can not be described, and measured or described through a quantitative approach.

For determining the number of samples is a very important part to do research. In EHRA study determining the sample of minimum size using the Slovin formula. The purpose of determining the type of samples is used to determine estimation of the population using the sample proportion.

Slovin formula as follows:

$$
n=\frac{N}{1+N e^{2}}
$$

Info:

$\mathbf{n}$ is the number of samples

$\mathbf{N}$ is the number of population

$\mathbf{e}$ is the sampling error is allowed

Subdistrict Bulak has a total population 42.978 people. With a degree of confidence in research by $90 \%$, then the error rate reached $10 \%$. By using the Slovin formula and with $10 \%$ a margin of error, obtained 99.9 number of samples, because the provisions of each village should be taken 40 samples in the study and in the district bulak EHRA there are 5 villages each district is required so that the 200 respondents said the data is valid.

\section{RESULTS AND DISCUSSION}

Respondents in formation in this study are described according to the group, the respondent's age, status occupied housing, education respondents, holdings are not able to, ownership of a health insurance card (Jamkesda), and possession of child respondents. It is very necessary because of the linkage with sanitation problems in the neighborhood. Sanitation facilities needs associated with the number of people who stay at home, therefore, the more the number of families who stay at home, the greater the required capacity and heavier loads also sanitation. 
Based on the results of EHRA studies that have been done, the number of respondents aged over 45 years is positioned on the highest $37 \%$, with the number of 73 respondents. While most of the status of their own homes and that $77 \%$ to 155 the number of respondents. this is very important information where the consequences of this condition lie in the availability of household sanitation facilities. Of the $23 \%$ of respondents who occupied the house that does not belong to themselves cant not tend to adjust sanitary facilities according to their needs and they also tend to have a low environmental awareness.

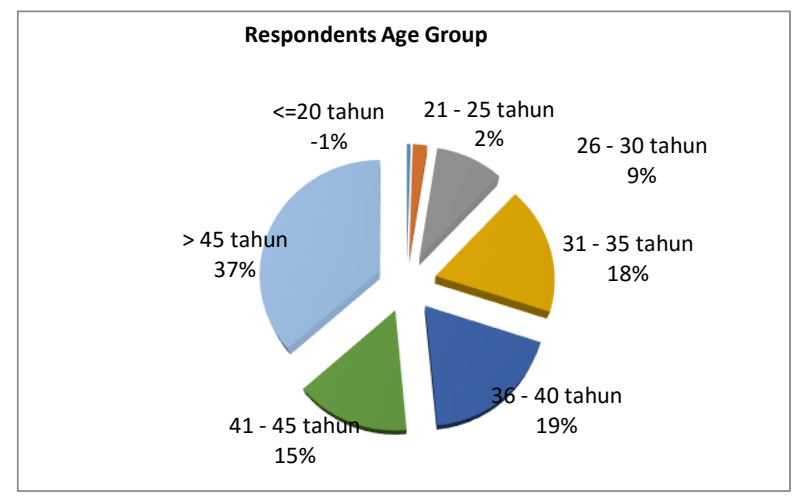

Figure. 1. Respondents Age Group

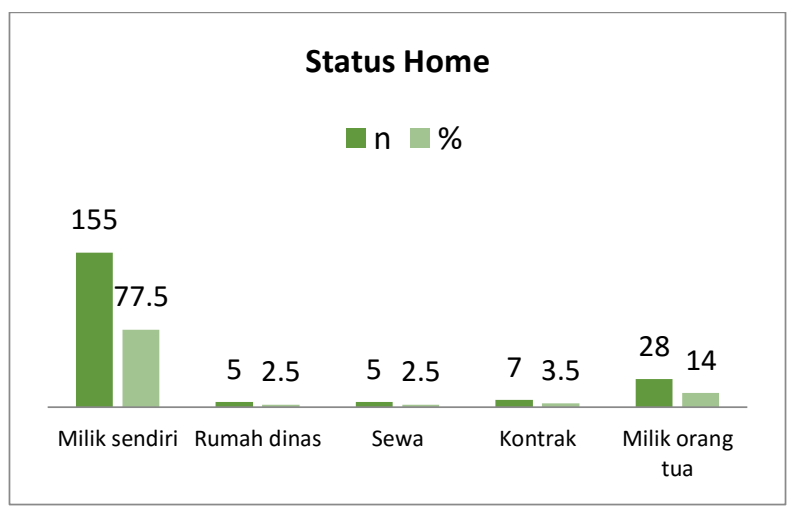

Figure. 2. Status Home

For the last educational status of respondents in the high school level has the highest percentage to $34 \%$, with the number of 68 respondents. The level of education is a very important factor which had an impact on the understanding and awareness of the sanitation infrastructure and facilities that exist in the environment. The higher educational level, the greater information obtained and also have a high awareness of environmental hygiene and solid waste management. 


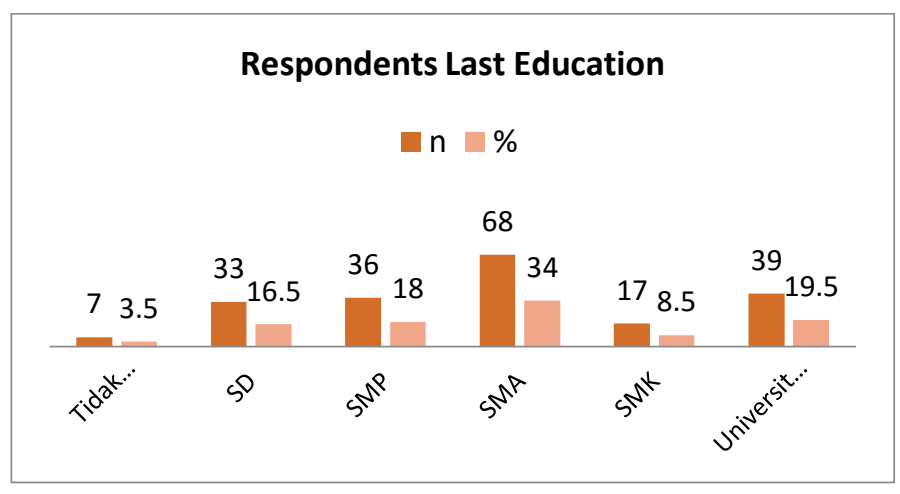

Figure. 3. Respondents Last Education

Based on the information obtained that the respondents who have a certificate cannot afford (SKTM) by $17 \%$. While respondents who had health insurance cards for poor families (ASKESIN) amounted to $60.5 \%$.For the respondents who have children in the home by $90 \%$.

\section{Household Waste Management}

The trash condition in bulakSurabaya, in total the highest indicator is given by the number of mosquitoes in the region amounted to $88.5 \%$ with the number of 177 respondents. Garbageconditions that was in the area is still carrying a lot of germs.

Respondents who perform household waste management to be collected and disposed to landfills while (TPS) of 98.5,. while carrying out waste management in a way is collected by informal collectors who recycle $1.5 \%$. Pattern garbage collection by Aswadi Mohammed et al (2011) uses direct communal pattern, where garbage collection is done by the people to the polling station or directly to the truck that came garbage collection point.

Based on the studies obtained, respondents who expressed not sorting garbage ie $80.5 \%$ with the number 161 of the 200 respondents, while sorting the garbage that is $19.5 \%$ with 39 of the 200 respondents totals. 


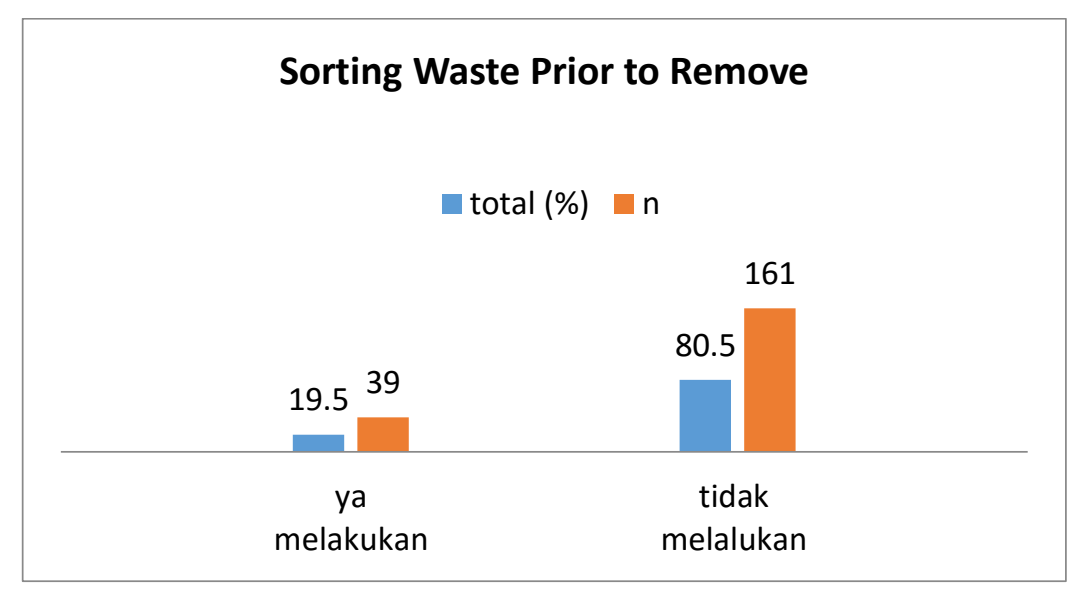

Figure. 4. Sorting Waste Prior to Remove

Based on waste sorting is done in the District of Bulak, the respondent through the trash, organic or wet waste by $53.8 \%$ with the number of 21 respondents.

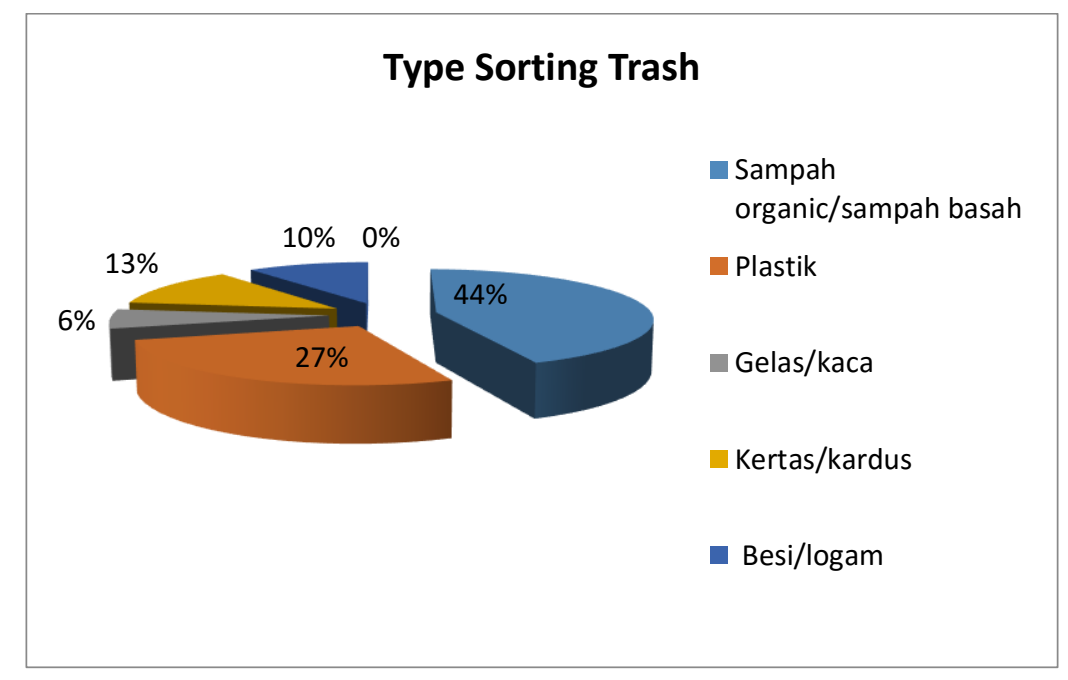

Figure. 5. Type Sorting Trash

Most of the District bulak, transporting waste by officers carried out several times a week by $72.5 \%$ with the number of 145 respondents. As for the transport of waste, every day amounted to $27.5 \%$ with the number of 55 respondents. Transporting waste carried by the officers associated with the prices already set in their respective territories. 


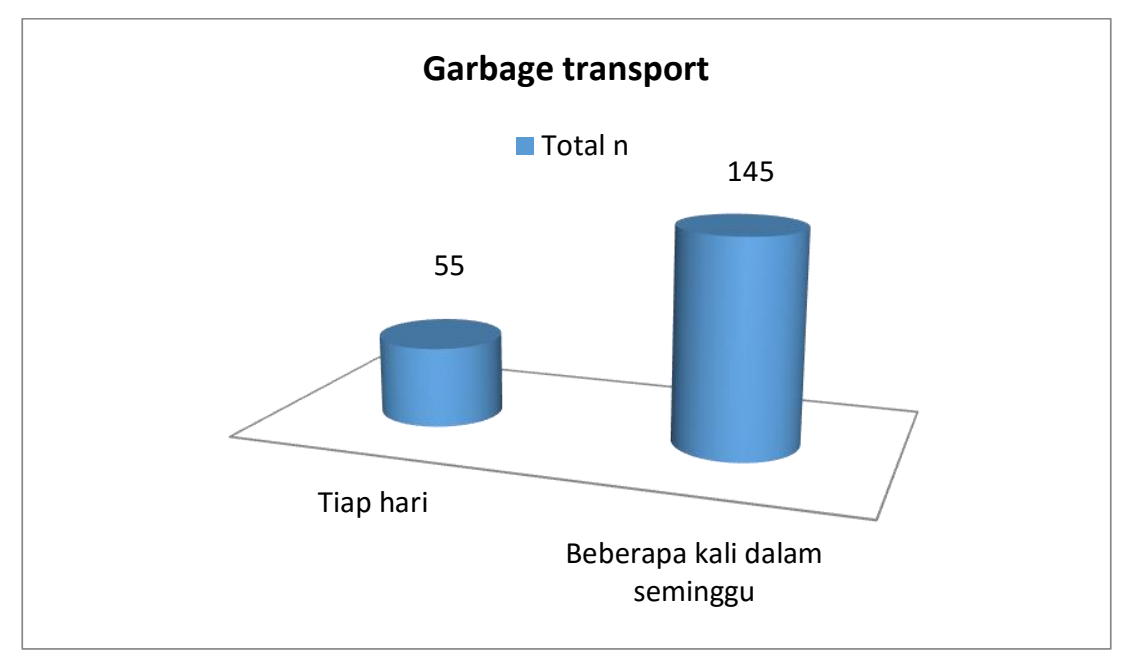

Figure. 6. Garbage transport

\section{CONCLUSION}

Territory District of Bulak community have not done the maximum waste management, where only some percent of respondents who pick through the trash, there are still people who use plastic bags as garbage containers and dispose of waste is not in place. Based upon the results of research studies EHRA in District of Bulak Surabaya there are 200 respondents, only a small proportion of respondents who undertake waste management such as collecting plastic bottles, collecting cardboard former, and glass with a percentage of $19.5 \%$ with the number of 39 respondents, while not doing $80.5 \%$ with the number of 161 respondents.

The Construction of district in the region, besides causing a positive impact, it can also affectnegatively for the socio-economic life of society in the region. Society in this region generally only has a very simple provision of education and health behavior tend to be relatively low in this region. This is a challenge for the government of Surabaya in waste management tomanifest the city clean and healthy.

SDGs Achievement in this study were taken in point 6 Water and sanitation where the mayor of Surabaya has a special treatment of waste, so the waste that goes to landfill was reduced by 40 tons a day.

\section{REFERENCE}

Aswadi, Muhammad.dkk. (2011). Waste Management Planning at the Housing Tavanjuka Mas. Tadukalo.Vol.13 University civil engineering journal, No02. Tadulako, Palu. 
Kardono, (2007). Integrated solid waste management in Indonesia. Proceedings of the International Symposium on Ecotopia Science 2007, ISETS07: 629 - 633. Jakarta.

Bulak sub-district in (2017). The Central Statistics Agency figures Surabaya BPS- Statistics of Surabaya Municipality. Kecamata Bulak. City of Surabaya.

Ministry of Environment (2008). Indonesian Domestic Solid Waste Statistics Year 2008. Ministry of Environment of the Republic of Indonesia.

Rizal, Muhammad. (2011). Analysis of Urban Waste Management. SMARTek Journal, Vol. 9 No. 2. May 2011: 155 - 172. Sigi regency, Central Sulawesi.http://jurnal.untad.ac.id/jurnal/index.php/SMARTEK/article/view File / 61 4/532 Downloaded 5 November 2018. 